\title{
AMPLIAÇÃO DA LICENÇA MATERNIDADE EM RAZÃO DO NASCIMENTO PREMATURO
}

EXPANSION OF THE MATERNITY LICENSE AS A PREMATURE BIRTH

Camila da Silva Alencar ${ }^{1}$

ISSUE DOI: $10.21207 / 1983.4225 .305$

\section{RESUMO}

O objetivo geral deste artigo é abordar os principais aspectos inerentes à licença-maternidade e elucidar os motivos pelos quais o aumento desse benefício às trabalhadoras mães de um bebê prematuro trará muitas vantagens não só para mãe e filho, mas também para a própria sociedade. A empregada que se encontra nessas circunstâncias não possui nenhum benefício especial para conviver com seu filho por mais tempo, situação em que não deve permanecer, tendo em vista todos os cuidados especiais que um recém-nascido prematuro exige, sem contar que, devido ao nascimento antes da hora, em muitos casos, o bebê precisa ficar internado até alcançar as condições mínimas necessárias para deixar o hospital. Quando isso acontece, a licença-maternidade concedida à mãe já está quase no fim, impossibilitando-lhe o acompanhamento no desenvolvimento inicial de seu filho. Verifica-se que os legisladores já vêm se preocupando com esse problema social, tanto que já existem diversos projetos de lei que corroboram essa tese. Contudo, todos ainda estão em processo de tramitação. Algumas cidades criaram leis municipais que concedem tal vanta-

${ }^{1}$ Graduanda em Direito pela Faculdade de Direito de Franca, cursando o último ano. Estagiária de Direito da Universidade de Franca (UNIFRAN). 
gem às suas servidoras. Considerando que mais de $11 \%$ das crianças nascidas no Brasil são prematuras, é necessário estabelecer um benefício que alcance todas as trabalhadoras, uma vez que se percebe, pela porcentagem apresentada, que a quantidade de mulheres prejudicadas pela falta de um amparo legislativo é bem significativa. Portanto, a melhor maneira de evitar prejuízos e transtornos a tantas mães que passam por essa situação delicada, garantir a saúde do prematuro, bem como seu direito aos cuidados maternos, será o aumento da licença-maternidade.

Palavras-chave: Direito do Trabalho. Benefício previdenciário. Licençamaternidade. Prematuro. Duração da licença-maternidade.

\section{ABSTRACT}

The general objective of this article is to address the main aspects of maternity leave and elucidate the reasons why increasing this benefit to working mothers of a preterm infant would bring many benefits not only to the mother and the child but also to the child society. The employee under these circumstances does not have any special benefit to live with her child any longer, a situation that should not remain in view of all the special care that a premature newborn requires, not to mention that due to premature birth, In many cases the baby must remain hospitalized until the minimum conditions necessary to leave the hospital are reached. When this period arrives, the maternity leave granted to the mother is almost at an end, making it impossible for the mother to accompany the mother in the initial development of her child for the time necessary so that her absence does not harm the child's health. It turns out that legislators have already been worrying about this social problem, there are several bills that corroborate with this thesis. However, all are still in the process of being processed. Some cities have created municipal laws that grant this advantage to their servants. Considering that more than $11 \%$ of the children born in Brazil are premature, it is necessary to establish a benefit that reaches all the workers, since it is perceived by the percentage presented that the amount of women harmed by the lack of a legislative shelter is quite significant. It is concluded that the best way to avoid harm and inconvenience to many mothers who go through this delicate situation and ensure the health of premature babies and their right to maternal care will be an increase in maternity leave. 
Keywords: Labor law. Social security benefit. Maternity leave. Premature. Maternity leave duration.

\section{INTRODUÇÃO}

É notória a angústia das mães que dão à luz a bebês prematuros, haja vista que não conseguem passar o tempo necessário prestando assistência a seu filho devido ao término do período de licença-maternidade. Não obstante, é evidente a necessidade de o bebê prematuro ficar mais tempo com a mãe.

Em razão do desamparo legislativo às trabalhadoras que passam por essa situação delicada, é feito o presente artigo para demonstrar o conteúdo existente sobre o assunto e as razões pelas quais a criança prematura e sua mãe merecem um benefício especial para que consigam vencer juntas todas as complicações que podem acontecer no início da vida de um recém-nascido pré-termo.

O bebê prematuro pode passar os primeiros meses de vida internado devido a sua fragilidade e necessidade de cuidados médicos pelo fato de seu desenvolvimento não estar completo, o que pode causar diversas dificuldades em sua saúde e prolongar sua estadia no hospital e até eventuais tratamentos após sua saída.

Assim, a mãe gasta grande parte de sua licença no período de internação da criança e quando o bebê está apto a receber alta, restam poucas semanas para a trabalhadora permanecer em casa para conferir ao bebê todos os cuidados necessários e, por vezes, a licença já terminou.

Devido aos cuidados especiais, torna-se mais difícil e inviável deixar o prematuro em creches, com terceiros ou em locais com outras crianças durante os seus primeiros meses de vida, por conta de toda a exposição do bebê, que possui uma fraca imunidade.

Tal realidade torna a problemática mais complicada e frustrante para as mães, que acabam por abandonar seus trabalhos para ficar cuidando da criança.

A concessão de um benefício especial a essas mães, para permanecerem mais tempo em casa com seus filhos prematuros, causaria um impacto bastante positivo, não só para e mãe e a criança, como também para a sociedade. 
Pretende-se esclarecer a importância do emprego de esforços para que o prematuro consiga superar todas as eventuais complicações que possam ocorrer em sua saúde, bem como prevenir de qualquer patologia que possa aparecer, tais cuidados não serão tomados tão bem quanto pela própria mãe, beneficiando o bebê e o próprio estado psicológico da mãe, que voltará a trabalhar com mais segurança e tranquilidade após um tempo maior com seu filho.

O primeiro tópico deste artigo dedica-se à abordagem das normas internacionais na legislação nacional e os direitos conquistados pelas mulheres ao longo da história dispostos na Organização Internacional do Trabalho, Consolidação das Leis do Trabalho, Constituição Federal e Lei 11.770/ 2008 (Lei da Empresa Cidadã).

O segundo tópico é reservado para um estudo geral sobre a licença-maternidade, destacando os seus principais aspectos como o conceito, sua duração e a distinção entre a licença-maternidade e o saláriomaternidade, a estabilidade da gestante e a carência do saláriomaternidade.

No terceiro tópico, são abordados os motivos da importância da mãe perto de seu filho prematuro nos primeiros meses de vida, os cuidados especiais de que precisa, ações realizadas para a população apoiar o projeto da Lei do Prematuro, algumas leis municipais que já concedem o aumento às suas servidoras, análise dos diversos Projetos de Lei que estão em tramitação e que corroboram com esta tese, bem como as disposições da legislação nacional que garantem direitos aos recém-nascidos.

A pesquisa parte do principio de que a dilação da duração dessa garantia estabelecida permitiria um avanço na efetividade da proteção social.

\section{EVOLUÇÃO DA LICENÇA-MATERNIDADE}

A Revolução Industrial foi um grande marco para a entrada da mulher no mercado de trabalho. Naquela época, mulheres e crianças ingressavam nas fábricas, realizavam jornadas exaustivas em situações 
precárias de trabalho, desempenhavam o mesmo trabalho que os homens por salários menores ${ }^{2}$, em outras palavras, eram facilmente exploradas.

Naquela época o Estado não intervinha nas relações trabalhis$\operatorname{tas}^{3}$, não se observava, pois, nenhum tipo de proteção à mulher na fase de gestação e amamentação.

Devido às circunstâncias desumanas vividas pelas mulheres e crianças no trabalho naquele período, foi dado início a uma série de questionamentos sobre a necessidade de uma proteção especial às mulheres e crianças na esfera trabalhista.

Em 1842, na Inglaterra, foram feitas as primeiras normas de proteção ao trabalho da mulher. Inicialmente, foi criado o Coal Mining Act, Factory Act em 1844 e Factory and Workshop Act de 1878, tratando respectivamente da proibição das mulheres em subterrâneos, a limitação do trabalho em até doze horas, vedando o trabalho no período noturno e o exercício do trabalho da mulher em ocupações perigosas e insalubres ${ }^{4}$.

No Brasil, a proteção à maternidade começou a surgir na época da Revolução de 1930 e da Presidência de Getúlio Vargas. ${ }^{5}$

Posteriormente, nota-se que a consideração pela mulher no trabalho aumentou, uma vez que a partir deste ponto a garantia de benefícios à maternidade e igualdade entre homem e mulher começam a surgir.

Por fim, conclui-se que as conquistas femininas na área trabalhista têm uma história recente.

\subsection{DA ORGANIZAÇÃO INTERNACIONAL DO TRABALHO}

A Organização Internacional do Trabalho - OIT foi criada por meio do Tratado de Versalhes em 25 de janeiro de $1919^{6}$. A proteção à

\footnotetext{
${ }^{2}$ RIBEIRO, Juliana de Oliveira Xavier. Salário-maternidade à luz da proteção previdenciária. Curitiba: Juruá, 2009, p. 19.

${ }^{3}$ ROCHA, Sílvia Regina da. O trabalho de mulher à luz da Constituição de 1988. Rio de Janeiro: Forense, 1991. p. 09.

${ }^{4}$ BOSSA, Sônia. Direito do trabalho da mulher no contexto social brasileiro e medidas antidiscriminatórias. São Paulo: Oliveira Mendes, 1998. p. 5.

${ }^{5}$ RIBEIRO, Juliana de Oliveira Xavier. Salário-maternidade à luz da proteção previdenciária. Curitiba: Juruá, 2009. p. 25.
} 
maternidade foi um dos primeiros assuntos abordados pela OIT para fins de normatização, assim como a proteção à identidade física da mulher e o tratamento igualitário entre os sexos. ${ }^{7}$

Primeiramente, a Convenção $n^{\circ} 03$ de 1919 garantiu o emprego da trabalhadora durante a licença, vedando sua dispensa; auxilio econômico pago pelo Estado ou órgão previdenciário e amparo médico gratuito; direito a dois repousos diários para a amamentação e por fim, a licença de 6 semanas antes e depois do parto, sendo o descanso antes do parto opcional e o posterior obrigatório. ${ }^{8}$

Devido a uma revisão realizada em 1952 na Convenção $n^{\circ}$ 03, foi criada a de $n^{\circ} 103$. A modificação foi realizada pelos países membros da OIT e a Organização Mundial da Saúde - OMS. A Convenção revista passou a valer em 1955 e foi ratificada pelo Brasil em 1965.

Sobre a Convenção no 103, Thaíssa Rocha Proni conclui que:

[...] entende-se como positiva a revisão ocorrida, pois englobou em seu conteúdo outras proteções, como licença integral em caso de parto prematuro e assistência médica durante todo o período gestacional e no pós-parto. ${ }^{9}$

No ano de 2000 , houve a criação da Convenção $n^{\circ} 183$, considerada de grande relevância devido à ampliação do período da licençamaternidade, de 12 semanas como era previsto na Convenção de 1952 , para 14 semanas. O Brasil não a ratificou ${ }^{10}$, mas mesmo sem ratificá-la,

\footnotetext{
${ }^{6}$ BOSSA, Sônia. Direito do trabalho da mulher no contexto social brasileiro e medidas antidiscriminatórias. São Paulo: Oliveira Mendes, 1998. p. 6.

${ }^{7}$ ROCHA, Sílvia Regina da. O trabalho da mulher à luz da Constituição de 1988. Rio de Janeiro: Forense, 1991. p 19.

${ }^{8}$ BACHUR, Tiago Faggioni; MANSO, Tânia Faggioni Bachur da Costa. Licençamaternidade e salário-maternidade: na teoria e na prática. Franca: Lemos e Cruz, 2011. p. 26 e 27.

${ }^{9}$ Ibidem. p. 51.

10 ORGANIZAÇÃO INTERNACIONAL DO TRABALHO. Convenções ratificadas pelo Brasil. Disponível em: 〈http://www.oitbrasil.org.br/convention>. Acesso em: 16 jul. 2015.
} 
já declarou a concessão de um período maior que o tipificado na Convenção, por meio de legislação pátria. ${ }^{11}$

Atualmente, a OIT vem realizando relevantes estudos para o aperfeiçoamento do tema maternidade, tendo em vista o grande aumento do prestígio da mulher no mercado de trabalho e a difícil conciliação entre trabalho e cuidados maternos.

É de fato bastante relevante a preocupação constante com a aprimoração das normas internacionais a respeito, sempre se dedicando à saúde e boa recuperação física e psicológica da mãe e da criança.

\subsection{CONSOLIDAÇÃO DAS LEIS DO TRABALHO}

A Consolidação das Leis do Trabalho - CLT entrou em vigor pelo Decreto Lei $\mathrm{n}^{\circ} 5.452$ de $1^{\circ}$ de maio de 1943 para unificar a legislação do trabalho no Brasil.

Os artigos de $n^{\circ} 391$ a 400 tratam especificamente da maternidade, com algumas modificações para assegurar mais garantias para a gestante e criança, bem como adequá-las às mudanças do mercado de trabalho.

No cenário atual, em síntese, a CLT garante, em seu artigo 392 e parágrafos, a licença- maternidade de 120 dias, sem prejuízo de emprego e salário, mesmo em caso de parto prematuro ${ }^{12}$, que é considerado aquele parto ocorrido antes de 37 semanas de gestação.

É garantida à trabalhadora a transferência de função caso necessário, bem como a dispensa para consultas médicas e exames. Ressalta-se que os direitos do artigo 392 estendem-se às empregadas que adotem ou obtenham a guarda judicial da criança.

Dos direitos da gestante tipificados na CLT destacam-se ainda a extensão da licença ou do resto dela ao cônjuge ou companheiro caso

\footnotetext{
${ }^{11}$ PRONI, Thaíssa Tamarindo da Rocha Weishaupt. Proteção constitucional à maternidade no Brasil: um caso de expansão da garantia legal. São Paulo: LTr, 2013. p. 55.

${ }^{12}$ BRASIL. Consolidação das Leis do Trabalho. Decreto-lei n. 5.452, de 01 de maio de 1943. Aprova a consolidação das leis do trabalho Art. $392 \S 3^{\circ}$. Em caso de parto antecipado, a mulher terá direito aos 120 (cento e vinte) dias previstos neste artigo. Disponível em: <http://www. planalto.gov.br/ccivil_03/decreto-lei/Del5452.htm>. Acesso em: 27 set. 2015 .
} 
ocorra a morte da mãe, conforme artigo 392-B; acesso a escolas maternais e jardins de infância para deixar a criança; descansos especiais à funcionária para amamentação durante os primeiros 6 meses de vida do bebê em locais com instalações básicas e adequadas, de acordo com os artigos 396 e 400 do diploma abordado.

Segundo o artigo 395, no caso de aborto não criminoso, é garantido à mulher repouso remunerado de 2 semanas.

A Súmula 244 do TST trata da estabilidade da gestante, e aborda três pontos importantes: o inciso primeiro relata que o desconhecimento do estado gravídico pelo empregador não afasta o direito ao pagamento da indenização decorrente da estabilidade.

O segundo inciso dispõe que a garantia de emprego à gestante só autoriza a reintegração se ocorrer durante o período de estabilidade. Do contrário, a garantia restringe-se aos salários e demais direitos do período de estabilidade. O terceiro consiste no direito da empregada gestante à estabilidade provisória prevista no art. 10, inciso II, alínea "b", do ADCT, mesmo na hipótese de admissão mediante contrato por tempo determinado.

O estado de gravidez ou o matrimônio não equivale a motivo de rescisão de contrato de trabalho, porém, conforme reza o artigo 394 da CLT, a gestante poderá romper o compromisso de trabalho firmado caso a execução desse seja prejudicial à gestação.

Para a confirmação de que tais normas que se mostram tão importantes sejam de fato cumpridas pelos empregadores, é imposta multa para caso de descumprimento da matéria abordada, consoante artigo 401 da CLT.

\subsection{PROTEÇÃO CONSTITUICIONAL À MATERNIDADE.}

O texto da Constituição Federal de 1988 tipificou, dentre outros direitos da mulher, a igualdade salarial entre os sexos, tornando o homem e mulher iguais em direitos e obrigações, conforme dispõe o inciso I do artigo $5^{\circ}$ da $\mathrm{CF} / 88$.

Dentre as normas desse diploma, foi estabelecida a proteção ao mercado de trabalho da mulher, com estímulos na forma da lei (art. $7^{\circ}$, $\mathrm{XX}$ ); assessoria gratuita aos filhos de até 5 anos de idade em creches e 
pré-escolas (art. $\left.7^{\circ}, \mathrm{XXV}\right)$; garantindo ainda, a proteção à maternidade (art. 201, II).

Ademais, elenca uma questão muito importante que é a vedação da dispensa arbitrária ou sem justa causa da trabalhadora gestante, até 5 meses após o parto. Tal norma encontra-se no Ato das Disposições Constitucionais Transitórias, art. 10, inciso II alínea b.

Neste sentido, a disposição mencionada possui objetivo de proteger a gestante e a saúde do bebê, garantindo seu direito fundamental.

Assim, nada mais justo do que o Estado ser o responsável em proteger e proporcionar uma ampla defesa e garantia dos direitos adquiridos pela mulher quando encontrar-se na execução de um contrato de trabalho e engravidar.

A licença-maternidade é um benefício previsto no rol dos direitos sociais da Constituição de 1988 , elencado nos arts. $6^{\circ}$ e $7^{\circ}$, XVIII. A Previdência Social foi designada para bancar o custo dessa garantia da gestante. $\mathrm{O}$ empregador custeia a licença e a quantia despendida é compensada nos outros valores pagos à Previdência.

Existem ainda, ocasiões em que a licença-maternidade é paga diretamente pelo INSS, casos como os das contribuintes que se encaixam na categoria de empregada doméstica, adotante de criança ou que obtiver a guarda judicial para fins de adoção, ${ }^{13}$ bem como a contribuinte individual e a facultativa. ${ }^{14}$

Desta forma, o INSS será o responsável pelo pagamento do chamado salário-maternidade durante a pausa da gestante, não prejudicando, portanto, a empresa e nem alimentando o preconceito da admissão da mulher no mercado de trabalho. ${ }^{15}$ Assim reza o art. 201, inciso II da Constituição Federal de 1988.

\subsection{LEI 11.770 DE 2008}

\footnotetext{
${ }^{13}$ DELGADO. Maurício Godinho. Curso de direito do trabalho. 14. ed. São Paulo: LTr. 2015. p. 1167.

14 TECNOLOGIA E INFORMAÇÕES DA PREVIDÊNCIA SOCIAL - DATAPREV. Requerimento de salário-maternidade - informações básicas. Disponível em: http://www.dataprev.gov.br/servicos/salmat/salmat_def.htm. Acesso em: 31. set. 2015. 15 CARRION, Valentin. Comentários à CLT: legislação complementar/ jurisprudência. 39 ed. rev. e atual. por Eduardo Carrion. São Paulo: Saraiva, 2014. p. 327.
} 
A Lei 11.770 de 09 de setembro de 2008 criou o Programa Empresa Cidadã, estabelecida para prorrogar a licença-maternidade por mais 60 dias mediante concessão de incentivo fiscal às empresas que aderirem ao programa. Essa Lei Federal foi regulamentada pelo Decreto n 7052 de 23 de dezembro de 2009.

O benefício tratado é concedido imediatamente após o término dos 120 dias garantidos pela Constituição Federal (art. $1^{\circ}, \S 1^{\circ}$ da Lei 11.770/2008). O programa é de adesão voluntária.

A trabalhadora deve receber o salário referente aos 60 dias adicionais da mesma forma que recebida durante os primeiros 120 dias de licença, período que é custeado pela Previdência Social.

Entretanto, o pagamento do segundo período não é de responsabilidade do INSS, mas sim do próprio empregador, que poderá deduzir os valores pagos dos impostos devidos, se preenchidos os requisitos estabelecidos em lei, que serão abordados neste tópico.

Em caso de adoção ou obtenção de guarda judicial com objetivo de adoção de criança, a empregada terá seus direitos garantidos nos mesmos termos concedidos à gestante, consoante art. $1^{\circ}, \S 2^{\circ}$ da Lei 11.770/2008.

Para que a empregada tenha direito ao benefício dos 60 dias adicionais, é necessário o preenchimento de três requisitos indicados na referida lei: o primeiro requisito é a adesão da empresa ou a instituição da administração pública direta, indireta e fundacional ao programa de prorrogação da licença, o segundo se refere à necessidade da empregada requerer o benefício até o final do primeiro mês após o parto.

Por fim, o terceiro requisito consiste na proibição da empregada beneficiária de exercer qualquer atividade remunerada, bem como a vedação de o bebê ser mantido em creche ou estabelecimento semelhante durante a licença, sob pena de perder o direito à prorrogação, conforme dispõe seu artigo $4^{\circ}$, parágrafo único, da Lei 11.770/2008.

$\mathrm{O}$ artigo $5^{\circ}$ do Decreto $n^{\circ} 7.052$ de 2009 abre uma exceção à proibição da empregada trabalhar durante a licença em casos de contrato de trabalho simultâneo firmado previamente com mais de um empregador.

A justificativa para o benefício, em suma, é assegurar o cumprimento do principio da proteção integral previsto no Estatuto da Criança e do Adolescente, bem como garantir o aleitamento materno privativo 
durante os primeiros seis meses de vida do bebê, respeitando a recomendação da Organização Mundial da Saúde - OMS. ${ }^{16}$

A Lei 11.770/2008 esclarece que poderão fazer jus ao benefício apenas as trabalhadoras da pessoa jurídica ou da entidade da Administração pública direta, indireta e fundacional que aderir ao programa, conforme dispõe seus artigos $1^{\circ} \S 1^{\circ}$ e art. $2^{\circ}$.

Ainda, de acordo com o artigo $5^{\circ}$ da lei em estudo, os valores pagos a título de salário para as trabalhadoras durante os 60 dias adicionais da licença, apenas poderão ser deduzidos do imposto de renda da empresa, caso esta seja tributada com base no lucro real.

Desta forma, as empresas que optam pelo SIMPLES e as enquadradas no regime do lucro presumido, não podem deduzir dos impostos a quantia paga.

Destarte, conclui-se que o direito ao afastamento maior não cabe às empregadas da pessoa física, do empregador doméstico ${ }^{17}$, das microempresas, empresas de pequeno porte, nem das esquadradas no regime de lucro presumido, por ficarem fora das especificações legais.

Isso posto, entende-se que apesar da nobre intenção de beneficiar a trabalhadora com uma licença maior, tal benefício pode trazer prejuízos para a empresa que não se enquadre nos quesitos expostos em lei, uma vez que, não recebendo o desconto devido dos valores pagos à trabalhadora, restará em prejuízo por não deduzir as quantias do imposto de renda devido. ${ }^{18}$

Assim, ainda é bem pequena a quantidade de empresas que aumentaram a duração da licença-maternidade.

\section{ASPECTOS GERAIS DA LICENÇA-MATERNIDADE}

\footnotetext{
${ }^{16}$ BRASIL. Senado Federal. Projeto de lei do Senado $\mathbf{n}^{\mathbf{0}} 281$ de 2005. Disponível em: http://legis. senado.leg.br/mateweb/arquivos/mate-pdf/6716.pdf. Acesso em: 17 ago. 2015.

${ }^{17}$ MARTINS, Sergio Pinto. Direito do trabalho. 30. ed. - São Paulo: Atlas, 2014. p. 672. ${ }^{18}$ Ibidem. p. 673.
} 


\subsection{CONCEITO DE MATERNIDADE E FINALIDADE DA LICENÇA}

A maternidade tem seu significado definido pelo Dicionário Michaelis como estado ou qualidade de mãe ou até mesmo como uma relação de parentesco, que liga a mãe e filho. ${ }^{19}$

A ideia de ligação descrita é de fato o que há de mais importante no conceito, uma vez que a maternidade consiste na conexão biológica e sentimental da mãe com o seu filho.

Como se não bastasse, a mulher ganha uma responsabilidade eterna para com seu filho, sendo que os casos não alcançáveis pela sua responsabilidade jurídica chegam à esfera moral e amorosa da mãe.

Assim, faz-se necessária uma proteção à mulher ao menos no período inicial destas mudanças, ou seja, quando a criança chega ao mundo, necessitando de seus cuidados.

Durante essa fase, a mãe se dedica exclusivamente ao bebê, não havendo, portanto, espaço, tempo ou emocional para o trabalho. Neste ponto, encontra-se a licença-maternidade tipificada nas seções V e VI da Consolidação das Leis do Trabalho e artigo $7^{\circ}$ da CF.

A licença-maternidade é um direito tutelado pelo Direito do Trabalho e consiste no afastamento da mulher de suas atividades laborais para o convívio com o filho, quando de seu nascimento ou da respectiva adoção. $^{20}$

A finalidade da licença-maternidade refere-se a vários fatores de proteção à mãe e ao bebê, como a amamentação adequada nos primeiros meses de vida, a recuperação física e mental da mulher após o parto, a adequação com seu filho, de modo que possa presenciar o crescimento e transmitir seu afeto tão importante para o desenvolvimento do recémnascido. $^{21}$

\footnotetext{
${ }^{19}$ WEISZFLOG, Walter. Michaelis moderno dicionário da língua portuguesa. Melhoramentos Ltda. nova ortografia, 2012. Conceito de Maternidade: ma.ter.ni.da.de - $s f$ ( $m a-$ terno $+i+d a d e) 1$ Estado ou qualidade de mãe. Disponível em: <http://michaelis .uol.com.br/moderno/portugues/index.php?lingua=portugues-portugues\&palavra=matern idade>. Acesso em: 02 set. 2015.

20 BACHUR, Tiago Faggioni; MANSO, Tânia Faggioni Bachur da Costa. Licençamaternidade e salário-maternidade: na teoria e na prática. Franca: Lemos e Cruz, 2011. p.17-18.

${ }^{21}$ Ibidem.
} 
Da Silva esclarece que: "A finalidade da licença não é apenas o repouso ou o restabelecimento do vigor da mulher, mas também o acompanhamento do recém-nascido em seus primeiros meses de vida"22.

Destarte, nota-se que a licença-maternidade tem uma importância fundamental para as mães, sendo que a próxima questão a ser observada é o lapso temporal de licença concedido à mulher.

\subsection{DURAÇÃO}

A empregada gestante não pode ser despedida sem justa causa durante a licença maternidade; desta forma, há um descanso obrigatório com a garantia de emprego, sendo assegurado o pagamento correspondente a essa pausa.

A Carta Magna vigente tipificou uma licença em 120 dias para a trabalhadora gestante, sem prejuízo do salário e emprego. As empregadas rurais, autônomas e as domésticas também estão incluídas para fazerem jus do benefício da licença-maternidade, conforme tratam os artigos 71 e seguintes da Lei $\mathrm{n}^{\circ} 8.213$ e artigo $7^{\circ} \S$ único da $\mathrm{CF}$.

O prazo demonstrado na atual Constituição é maior que o exigido pela OIT, em sua Convenção de $n^{\circ} 183$, que dispõe a licença mínima de 14 semanas.

A licença pode ter inicio entre o $28^{\circ}$ dia antes do parto e a ocorrência deste, mediante apresentação de atestado médico. Por meio desse atestado, a gestante deve notificar o empregador sobre a data de início da sua ausência, conforme artigo $392 \S 1^{\circ}$ da CLT.

$\mathrm{O}$ afastamento iniciado após o $28^{\circ}$ dia não prejudica os 120 dias de duração, em que poderão ser gozados posteriormente integralmente. ${ }^{23}$

De acordo com o artigo $392 \S 2^{\circ}$ da CLT, é possível que ocorra um aumento da licença por um lapso de duas semanas caso ocorram perigos na gestação ou com a vida do bebê.

\footnotetext{
${ }^{22}$ DA SILVA, Homero Batista Mateus. Curso do direito aplicado. Segurança e medicina do trabalho, trabalho da mulher e do menor. São Paulo: Campus Jurídico, 2009. p. 172

23 NASCIMENTO, Amauri Mascaro. Iniciação ao Direito do Trabalho. 37. ed. São Paulo: LTr. 2012. p. 201.
} 


\subsection{A ESTABILIDADE DA GESTANTE E A LICENÇA- MATERNIDADE}

A estabilidade da gestante não se confunde com a licençamaternidade, sendo que aquela consiste na vedação de sua dispensa do trabalho sem justa causa por certo período. Antes da CF/88, tal benefício era previsto em Convenções Coletivas de trabalho ${ }^{24}$.

O artigo 10, II, "b" do ADCT da Constituição Federal de 1988 esclarece que é vedada a dispensa arbitrária ou sem justa causa da empregada gestante, desde a confirmação da gravidez até cinco meses após o parto.

Na hipótese do empregador desconhecer a qualidade de gestante de sua empregada, no momento de despedida imotivada, aplica-se inciso I da Súmula 244 do TST ${ }^{25}$.

Existem duas teorias a respeito da estabilidade da gestante quanto a confirmação da gravidez: a teoria da responsabilidade subjetiva defende que a empregada deve comprovar a gravidez ao empregador, por meio de exame laboratorial ou atestado médico ${ }^{26}$ e a teoria da responsabilidade objetiva, que toma por base a confirmação da gravidez para a própria empregada, a garantia de estabilidade independe do conhecimento do empregador. Este é o entendimento adotado pelo TST e pela atual jurisprudência.

Na hipótese de a empregada provar sua gravidez durante o aviso prévio, consoante artigo 391-A da CLT, terá direito à garantia de emprego, uma vez que, o contrato de trabalho termina apenas no último dia do aviso prévio indenizado, conforme artigo $487 \S 1^{\circ}$ da CLT.

\footnotetext{
24 NASCIMENTO, Amauri Mascaro. Curso de Direito do Trabalho: história e teoria geral do direito do trabalho, relações individuais e coletivas do trabalho. 27. ed. São Paulo: Saraiva, 2012. p. 935.

${ }^{25}$ GESTANTE. ESTABILIDADE PROVISÓRIA (redação do item III alterada na sessão do Tribunal Pleno realizada em 14.09.2012) - Res. 185/2012, DEJT divulgado em 25, 26 e 27.09.2012. I - O desconhecimento do estado gravídico pelo empregador não afasta o direito ao pagamento da indenização decorrente da estabilidade (art. 10, II, "b" do ADCT ex-OJ n ${ }^{\circ} 88$ da SBDI-1 - DJ 16.04.2004 e republicada DJ 04.05.04)

26 JORGE NETO, Francisco Ferreira; CAVALCANTE, Jouberto de Quadros Pessoa.
} Direito do trabalho. 7 ed. São Paulo. Atlas. 2013. p. 923 
A CF garante a estabilidade da trabalhadora gestante desde o momento de confirmação do estado gravídico até cinco meses após o parto (Art. 391-A da CLT).

A mulher empregada mediante contrato por tempo determinado, também será beneficiada da estabilidade provisória, conforme entendimento do TST na Súmula 244, III.

Além disso, a Orientação Jurisprudencial no 30 da Seção de Dissídios Coletivos - SDC dispõe que a cláusula que estabelece a possibilidade de renúncia ou transação, pela gestante, das garantias referentes à manutenção do emprego e salário é nula de pleno direito.

Ao analisar as mudanças a respeito do assunto, verifica-se que uma perspectiva mais humanitária vem sendo aplicada nas decisões judiciais, certificando a aplicação do princípio da dignidade da pessoa humana nas relações trabalhistas envolvendo a maternidade.

\subsection{DA CARÊNCIA DO SALÁRIO-MATERNIDADE}

O período de carência, conforme artigo 24 da Lei $n^{\circ} 8.213 / 91$, consiste no número mínimo de contribuições mensais indispensáveis para que o beneficiário do Regime Geral de Previdência Social faça jus ao benefício, a partir do transcurso do primeiro dia dos meses de suas competências.

Para desfrutar do salário-maternidade, não há carência para as beneficiárias empregadas, para a trabalhadora avulsa e as empregadas domésticas, desde que atestem filiação em uma dessas condições quando do afastamento para o propósito de receber salário-maternidade ou na data do parto. $^{27}$

Contudo, exige-se um período de carência das trabalhadoras que se encaixam como contribuintes facultativas, especiais ou individuais. ${ }^{28}$

Para que as três categorias de seguradas citadas tenham direito ao salário-maternidade, a carência condiz a dez contribuições mensais, a

\footnotetext{
27 BACHUR, Tiago Faggioni; MANSO, Tânia Faggioni Bachur da Costa. Licençamaternidade e salário-maternidade: na teoria e na prática. Franca: Lemos e Cruz, 2011. p.115.

${ }^{28}$ RIBEIRO, Juliana de Oliveira Xavier. Salário-maternidade à luz da proteção previdenciária. Curitiba: Juruá, 2009. p.57-58.
} 
contar com base da primeira prestação paga tempestivamente; assim dispõem os artigos 25, III e 27, II da Lei 8.213 de 1991.

Reputa-se importante ressaltar que a segurada individual ou facultativa, poderá ter menos que dez contribuições antes de dar à luz, desde que acrescentadas com as anteriores, que atinjam o mínimo estipulado antes do parto, devendo contribuir ao menos com um terço dos dez meses exigidos, conforme dispõe o parágrafo único do artigo 24 da Lei 8.213/91.

Foi criado um benefício exclusivo para a trabalhadora rural no tocante ao recebimento do salário-maternidade. A segurada especial que comprovar suas atividades rurais nos últimos dez meses anteriores ao requerimento, mesmo que inconstantes, poderá ter direito ao saláriomaternidade independentemente das contribuições, em conformidade com o artigo 93, $\S 2^{\circ}$ do Decreto $n^{\circ} 3048$ de 1999.

Em caso de antecipação do parto, o período de carência será reduzido ao número correspondente ao de meses em que o parto se antecipou, de acordo com o parágrafo único do artigo 29 do Decreto 3.048 de 1999.

Assim, verifica-se que as contribuintes facultativas e individuais precisam preencher o período de carência para receber o saláriomaternidade, enquanto as demais categorias de seguradas estão dispensadas, desde que comprovem os requisitos exigidos para cada caso.

Quanto à licença-maternidade, não há de se falar nesse benefício para as seguradas facultativas, individuais e especiais, tendo em vista que é um benefício exclusivo da contribuinte empregada. Portanto, não há de se exigir nenhuma carência e não há uma obrigatoriedade de afastamento de suas atividades. ${ }^{29}$

Desta forma, deve-se esclarecer que o salário-maternidade e a licença-maternidade são institutos distintos.

\subsection{DISTINÇÃO ENTRE A LICENÇA-MATERNIDADE E O SALÁRIO-MATERNIDADE}

\footnotetext{
29 BACHUR, Tiago Faggioni; MANSO, Tânia Faggioni Bachur da Costa. Licençamaternidade e salário-maternidade: na teoria e na prática. Franca: Lemos e Cruz, 2011. p. 116.
} 
A licença-maternidade e o salário-maternidade são em várias ocasiões tratados como se fossem o mesmo benefício. Contudo, cada um tem significado diverso, tendo como características semelhantes apenas o fato gerador - o nascimento ou a adoção (ou guarda para fins de adoção) ${ }^{30}$ e a extrema importância para a trabalhadora gestante.

A licença-maternidade é um direito protegido pelo Direito do Trabalho, que consiste no período que a mulher se afasta de suas atividades laborais em virtude do nascimento do bebê.

Tipificada no artigo $7^{\circ}$, XVIII da CF e artigo 392 da CLT, a licença-maternidade garante o afastamento da contribuinte empregada, sem prejuízo do salário e emprego por um período de 120 dias.

Por sua vez, o salário-maternidade é um benefício previdenciário suportado pelo INSS, a que a trabalhadora contribuinte tem direito, em razão do parto, da adoção ou da guarda judicial para adoção. Esse benefício é recebido, em regra, quando a grávida estiver no período de 28 dias antes e 91 dias depois do parto. ${ }^{31}$

Marcelo Leonardo Tavares explica a finalidade do saláriomaternidade: "O salário-maternidade, juntamente com o salário família, é um dos benefícios que visam à cobertura dos encargos familiares. Tem por objetivo a substituição da remuneração da segurada gestante durante os cento e vinte dias de repouso, referentes à licença-maternidade". ${ }^{32}$

Configura um direito da segurada empregada, avulsa, doméstica, individual, facultativa e especial, ou seja, esse benefício não se restringe apenas à empregada, mas amplia seu campo de aplicação a todas as categorias de contribuintes da Previdência Social. ${ }^{33}$

Em se tratando de trabalhadora empregada, a Previdência Social arca indiretamente com o salário-maternidade; já nos casos da beneficiária se enquadrar como contribuinte individual, facultativa, especial, empregada doméstica, desempregada que ainda se encontrar na qualidade de

30 BACHUR, Tiago Faggioni; MANSO, Tânia Faggioni Bachur da Costa. Licençamaternidade e salário-maternidade: na teoria e na prática. Franca: Lemos e Cruz, 2011. p. 17.

${ }^{31}$ RIBEIRO, Juliana de Oliveira Xavier. Salário-maternidade à luz da proteção previdenciária. Curitiba: Juruá, 2009. p. 48.

32 TAVARES, Marcelo Leonardo. Direito previdenciário. Rio de Janeiro: Lumen Juris, 2008. p. 160.

${ }^{33}$ RIBEIRO, Juliana de Oliveira Xavier. Salário-maternidade à luz da proteção previdenciária. Curitiba: Juruá, 2009. p. 57. 
segurada, bem como a adotante, o INSS paga o benefício diretamente, que deve ser requerido nas Agências da Previdência Social. ${ }^{34}$

Ambos os benefícios propiciam a harmonia entre a relação da mãe com o bebê, tendo por objetivo o desenvolvimento das relações de afeto e empatia entre eles, melhorando ainda as condições de vida e saúde de ambos. ${ }^{35}$

\section{DA LICENÇA-MATERNIDADE PARA MÃES DE PREMATUROS}

\subsection{A IMPORTÂNCIA DA PRESENÇA DA MÃE NOS PRIMEIROS MESES DE VIDA DO RECÉM-NASCIDO PREMATURO}

O nascimento de um bebê antes do tempo acarreta diversas sensações nos familiares e principalmente na mãe. Essas crianças necessitam, na maioria dos casos, de longas internações, fato que separa a família do convívio normal com o pequeno, podendo causar grande estresse psicológico e medo. ${ }^{36}$

Dentre os sentimentos mais presentes na mãe de um prematuro, encontram-se o medo, a tristeza e a culpa, que se desdobram em desgosto e aflição. A culpa é justificada pela necessidade da mãe em legitimar os motivos pelos quais seu bebê nasceu prematuro, bem como por sua insegurança $^{37}$. Desta forma, toda a estruturação entre mãe e filho fica afetada.

\footnotetext{
${ }^{34}$ GRANADEIRO.ADV. Benefícios: quem tem direito e como requerer o saláriomaternidade. Disponível em: <http://www.granadeiro.adv.br/template/template_c lipping.php?Id=3005>. Acesso em: 31 jul. 2015.

35 BACHUR, Tiago Faggioni; MANSO, Tânia Faggioni Bachur da Costa. Licençamaternidade e salário-maternidade: na teoria e na prática. Franca: Lemos e Cruz, 2011. p. 19.

${ }^{36}$ FONSECA, Luciana Mara Monti; SCOCHI, Carmen Gracinda Silvan. Cuidados com o bebê prematuro: orientações para a família. 2. ed. Ribeirão Preto. FIERP, 2005. $60 \mathrm{f}$. Cartilha Educativa (Mestrado em Enfermagem em Saúde Pública) - Escola de Enfermagem de Ribeirão Preto/USP, 2005.

${ }^{37}$ FRAGA, Iara Teresinha Gama. PEDRO Eva Néri Rubim. Sentimentos das mães de recém-nascidos prematuros: implicações para a enfermagem. Revista Gaúcha Enfer-
} 
Os primeiros meses após a saída do prematuro do hospital são muito delicados devido a sua baixa imunidade e possíveis problemas na visão, audição, vias aéreas, cérebro, coração e ao baixo peso ${ }^{38}$, uma vez que está mais exposto e deve ser acompanhado de perto pela mãe, pediatra e por especialistas, de modo que evitem a tempo qualquer problema ou complicação em sua saúde.

A realidade de muitas mães, nos primeiros meses do bebê prematuro, é muito corrida e cheia de responsabilidades, assim, resta claro que não há espaço para o trabalho.

O prematuro requer cuidados especiais, pois está com a saúde instável, conhecida como imaturidade orgânica. O bebê possui defesas fracas contra infecções e tem a pele fina. $\mathrm{O}$ nascimento antes do tempo pode prejudicar o desenvolvimento do bebê; assim, o acompanhamento médico e um cuidado maior da mãe são de suma importância. ${ }^{39}$

Outrossim, além dos fatores já abordados que provam a necessidade da mãe junto ao bebê nos primeiros meses, deve-se ressaltar que o leite materno durante o período inicial de vida da criança é o modo mais seguro de alimentar o bebê depois que ele sai do hospital.

O leite materno produz uma junção de carboidratos, minerais, vitaminas, lipídios, proteínas, enzimas e células vivas, com significativos benefícios imunológicos e nutricionais para o bebê prematuro, ${ }^{40}$ ou seja, proporciona os nutrientes necessários para um desenvolvimento saudável.

Desta forma, são evidentes os benefícios do prematuro ao tomar o leite materno. Verifica-se ainda, um direito da mãe e do bebê em ser amamentado, neste entendimento, Carlos de Oliveira Ramos explana:

magem. Porto Alegre, 2004, p. 89-97. Disponível em: http://www.seer.ufrgs.br/RevistaGauchadeEnfermagem/article/viewFile/4497/2434. Acesso em: 31 jul. 2015.

38 ALVES, Joana. Bebê prematuro: os cuidados vão muito além da UTI neonatal. Disponível em: http://barrigudos.blogosfera.uol.com.br/2013/08/24/maes-de-prematurosprecisam-de-licenca-maternidademaior/ Acesso em: 31 jul. 2015

${ }^{39}$ FONSECA, Luciana Mara Monti; SCOCHI, Carmen Gracinda Silvan. op. cit.

${ }^{40}$ NASCIMENTO, Maria Beatriz R. do; ISSLER, Hugo. Aleitamento materno em prematuros: manejo clínico hospitalar. Sociedade Brasileira de Pediatria, Jornal de Pediatria, Vol. 80, $\quad \mathrm{N}^{\circ} 5$ (supl), 2004. Disponível em: http://www.scielo.br/pdf/jped/v80n5s0/v80n5s0a 08.pdf. Acesso em: 31 jul. 2015. 
É inegável a conveniência do aleitamento das crianças por suas próprias genitoras. Todos os pediatras a externam e aconselham. É de tal sorte significativa e preponderante, na vida infantil, a amamentação, que não se pode considerar amplamente mãe a mulher que não a provê aos seus rebentos. (...) Por isso, pelo menos depois que, dado o progresso da ciência nos tempos modernos, se constatou que é um verdadeiro crime, um atentado à sociedade, o subtrair o filho inteiramente ao carinho, ao zelo e ao cuidado de sua mãe, é que as legislações cuidam de tão importante matéria e a regulam no interesse da criança. ${ }^{41}$

O crescimento e desenvolvimento saudável de uma criança, desde antes do parto, depende de inúmeros aspectos, principalmente no que se refere aos laços afetivos criados entre os pais e os filhos nos primeiros seis meses de vida, sendo fundamental para a evolução de uma criança sadia em um adulto possuidor de bases plácidas, corretas e prolíferas. $^{42}$

\subsection{CUIDADOS ESPECIAIS NECESSÁRIOS COM UM BEBÊ PREMATURO}

O bebê prematuro é aquele que nasceu antes da trigésima sétima semana de gestação. Os recém-nascidos prematuros podem ser classificados pela quantidade de semanas gestacionais e pelo peso.

O bebê pré-termo limiar é aquele que nasce entre a $33^{\mathrm{a}}$ e a $36^{\mathrm{a}}$ semana de gestação, ou com peso entre $1,5 \mathrm{~kg}$ e $2,5 \mathrm{~kg}$; o prematuro moderado é o bebê nascido entre a $28^{\mathrm{a}}$ e a $32^{\mathrm{a}}$ semana ou pesando de $1 \mathrm{~kg}$ a

\footnotetext{
41 SILVA. Aarão Miranda da. O Direito do Trabalho da mulher e a maternidade. Disponível em: <http://www.ambito-juridico.com.br/site/index.php?n_link=revista_artig os_leitura\&artigo_id=1751>. Acesso em: 31 set. 2015.

${ }^{42}$ SOCIEDADE BRASILEIRA DE PEDIATRIA. Minuta do projeto para o serviço público. Disponível em: <http://www.sbp.com.br/src/uploads/2014/10/minutado projetoparaoservicopublico.pdf>. Acesso em: 31 jul. 2015.
} 
$2,5 \mathrm{~kg}$ e por fim, o prematuro extremo é o que nasce antes de alcançar a $28^{\mathrm{a}}$ semana de idade gestacional ou o que pese menos de 1 quilo. ${ }^{43}$

Quanto menor a idade gestacional do bebê no momento do nascimento, mais o bebê terá que se desenvolver fora da barriga da mãe, assim, ele pode nascer sem conseguir respirar sem ajuda de aparelhos e pode ter um atraso em seu crescimento neurológico. ${ }^{44}$

Ainda, o pouco tempo de gestação implica em um risco maior de complicações no desenvolvimento do bebê, ficando mais vulnerável a pegar infecções, dificuldades com a sucção para mamar e seu sistema gastrointestinal ainda é bem imaturo, o que facilita o refluxo. ${ }^{45}$

Logo, quando o recém-nascido prematuro deixa o hospital, é necessário todo um cuidado especial, como a higiene da casa, do ambiente e das pessoas; nesta fase, permanecem nos pais os sentimentos de felicidade e medo juntos. ${ }^{46}$

Em 2013 foi divulgada uma pesquisa em que verificou que $11,7 \%$ das crianças nascidas no Brasil são prematuras ${ }^{47}$. Em 2010 o Brasil ocupou o $9^{\circ}$ lugar do ranking mundial de nascimentos prematuros ${ }^{48}$. Tais dados tendem a reflexão sobre a quantidade de mães que sofrem

43 DE MAE PARA MAE. Como cuidar de um bebê prematuro. Disponível em: http://demaeparamae.pt/ artigos/como-cuidar-bebe-prematuro. Acesso em: 31 jul. 2015. ${ }^{44}$ ABC.MED. Entendendo a prematuridade e os cuidados necessários com os prematuros. Disponível em: <http://www.abc.med.br/p/saude-da-crianca/502030/ent endendo-a-prematuridade-e-os-cuidados-necessarios-com-os-prematuros.htm>. Acesso em: 31 jul. 2015.

${ }^{45}$ SANTOS, Vera. Cuidados ao bebê prematuro. Disponível em: <http://www.janelaaberta-familia.org/pt/content/cuidados-ao-beb\%C3\%A9-prematuro>. Acesso em: 25 jul. 2015.

46 (...) os pais costumam relatar um sentimento ambíguo: felicidade extrema por ver seu bebê sair vitorioso e poder tê-lo em casa, e também muito medo, pois a partir dali terão que contar somente com os cuidados da família, sem auxílio de equipamentos e profissionais para monitorar a saúde dos pequenos. BALOGH, Giovanna. A curta licençamaternidade das mães de prematuros. Disponível em: http:// maternar.blogfolha.uol.com.br/2014/07/01/a-curta-licenca-maternidade-das-maes-deprematuros/. Acesso em: 01 ago. 2015.

47 UNICEF. Estudo faz alerta sobre a situação da prematuridade no Brasil. Disponível em: <http://www.unicef.org/brazil/pt/media_25849.htm>. Acesso em: 1 ago. 2015. 
junto com seu bebê prematuro ao deixá-lo logo nos primeiros meses de vida para voltar ao trabalho, mesmo com todas as responsabilidades inerentes à mãe de um prematuro.

Isto posto, a licença-maternidade de quatro meses para as mães acarreta prejuízos para a criança prematura, uma vez que parte do contato direto com a mãe é perdido, desconsiderando a atenção redobrada que um prematuro exige, e ainda prejudicando a amamentação. ${ }^{49}$

\subsection{AÇÕES REALIZADAS EM PROL DO AUMENTO DA DURAÇÃO DA LICENÇA-MATERNIDADE}

O aumento da licença-maternidade é um desejo de grande parte das mulheres mães de um bebê que nasceu antes do tempo, tendo em vista todas as implicações que eventualmente podem ocorrer na saúde da criança e a sua grande fragilidade nos primeiros meses de vida.

Os 120 dias tipificados na CLT, ou até mesmo os 180 dias fornecidos às trabalhadoras empregadas públicas ou de empresas que aderiram o Programa Empresa Cidadã, podem não ser suficientes para que a mãe de um prematuro consiga se adequar às necessidades da criança, participar de seu desenvolvimento e prestar toda a assistência especial que um prematuro necessita.

Em razão do drama social vivido por essas mães, surgiram alguns projetos através de iniciativas de sites, de mães desamparadas e de pessoas especialistas no assunto, que convivem de perto com as dificuldades passadas pelas mães na fase inicial da vida de seu filho pré-termo.

Em 2011, houve uma iniciativa do portal Aleitamento.com em parceria com Prematuridade.com, no qual divulgaram um link para os defensores participarem de um abaixo assinado criado com o fim de chamar atenção dos responsáveis sobre a importância de um aumento da

48 VEJA. Nascem 15 milhões de bebês prematuros por ano em todo o mundo. Disponível em: http://veja.abril.com.br/noticia/saude/nascem-15-milhoes-de-bebesprematuros-por-ano-em-todo-omundo/. Acesso em: 01 ago. 2015.

${ }^{49}$ BALOGH, Giovanna. A curta licença-maternidade das mães de prematuros. Disponível em: http://maternar.blogfolha.uol.com.br/2014/07/01/a-curta-licenca-maternidadedas-maes-de-prematuros/. Acesso em: 01 ago. 2015. 
licença-maternidade para mães de prematuros e o movimento já conta com mais de dez mil assinaturas. ${ }^{50}$

As justificativas do abaixo assinado envolvem estatísticas e exemplos sobre as possíveis complicações na saúde da criança prematura, assim, não se deve considerar o bebê pré-termo da mesma forma de uma criança nascida a termo, tendo em vista as desvantagens do prematuro em terminar seu desenvolvimento inicial fora do útero da mãe, tempo em que passa em uma incubadora na UTI de um hospital. ${ }^{51}$

Os apoiadores da ideia defendem a aprovação da Lei do Prematuro, através da qual a licença-maternidade passaria a ser contada a partir da $37^{\circ}$ semana, mesmo que o bebê tenha nascido antes. Assim, a mãe teria os 120 dias mais o período em que o nascimento foi antecipado ${ }^{52}$, o que na visão dos defensores, parece mais justo com as mães e com as crianças que precisam de contato direto por mais tempo.

Existe ainda, uma petição criada no site Avaaz.org - Petições da Comunidade, que também apoia a Lei do Prematuro e conta com mais de 2.500 assinaturas.

De acordo com as explicações sobre a importância da petição, que será entregue a Deputados e Senadores, é esclarecido que o contato mãe-bebê protege o recém nato de doenças, diminuindo a mortalidade infantil, doenças e problemas futuros, consequentemente havendo um decréscimo do absenteísmo da mulher no trabalho, minimizando gastos sociais com internações, medicamentos e reabilitações. ${ }^{53}$

Assim sendo, resta evidente a quantidade de pessoas que estão dispostas a apoiar projetos de ampliação da licença-maternidade em casos de nascimentos prematuros, números que certamente ultrapassam os assinados nos projetos, tendo em vista o volume de casos prematuros ocorrentes todos os dias em nosso país.

\footnotetext{
50 Aleitamento.COM. A Lei do Prematuro. Disponível em: <http://www.aleitamento.com/campanhas/lei-prematuro.asp>. Acesso em 15 nov. 2015.

${ }^{51}$ Ibidem.

52 Ibidem.
}

53 AVAAZ.ORG. Lei do prematuro - por que isto é importante. Disponível em: https://secure.avaaz. org/po/petition/Lei_do_Prematuro/?pv=1. Acesso em: 01 ago. 2015. 


\subsection{INSTITUTOS QUE PROTEGEM A CRIANÇA RECÉM NASCIDA}

Com a vigência da Constituição Federal de 1988, que se baseia no amparo à dignidade da pessoa humana, a proteção aos direitos humanos passou efetivamente a fundamentar a organização da sociedade brasileira. ${ }^{54}$

O recém-nascido também está incluído dentre os sujeitos de direito, os artigos $1^{\circ}$ e $2^{\circ}$ do Código Civil vigente, garante direitos a todos, atribuindo-lhes personalidade civil a partir do nascimento com vida.

Dentre os direitos fundamentais certificados à criança, encontrase o direito à vida, à educação, à liberdade, ao respeito, à dignidade e à convivência familiar, previstos na Constituição Federal, em seu artigo 227.

Após o estabelecimento de tais garantias às crianças e recémnascidos, nota-se também um progresso na conscientização da importância dos cuidados que devem ser despendidos à criança, objetivando um crescimento saudável físico e psicológico. ${ }^{55}$

O Estatuto da Criança e do Adolescente confere aos pais o dever de sustento, guarda e educação dos filhos menores, conforme primeira parte de seu artigo 22.

Por diversos meios, a legislação confere aos pais o dever de cuidar de seus filhos, de dar-lhes educação, uma boa saúde e convivência familiar. Contudo, nos casos de trabalhadoras mães de prematuros, a própria lei a desampara, não fornecendo condição de cumprir com seu dever de mãe.

A criança pré-termo, da mesma maneira, encontra-se desprovida de seus direitos, conferidos pela própria Constituição Federal, tendo em vista que com a pequena licença maternidade e paternidade atribuídas a seus pais, tem sua dignidade ferida e sua convivência familiar abalada, justamente por precisar dos pais por um tempo maior, devido aos cuidados especiais de que necessita.

\footnotetext{
${ }^{54}$ CHAVES, Adalgisa Wiedemann et al: coord: Belmiro Pedro Welter, Rolf Hanssen Madaleno. Direitos fundamentais do direito de família. Livraria do advogado. Porto Alegre, 2004. p. 279.

55 Ibidem. p. 284.
} 
Com o término da licença, o prematuro ainda requer da mãe por um tempo maior os períodos conferidos para pausas de amamentação, o que fere seu direito a conviver com sua família, precisa de acompanhamento médico com maior frequência e os pais não podem sair do trabalho para levá-lo, ferindo seu direito à saúde e entre outras situações que a criança vivencia sem seus pais por perto.

Assim, resta claro que o amparo da mãe nos primeiros meses de vida do recém-nascido prematuro é um direito expresso em vários institutos do ordenamento brasileiro e tais disposições devem ser observadas pela legislação trabalhista e previdenciária, de modo que caminhem juntas, protegendo as necessidades de cada criança.

\subsection{JURISPRUDÊNCIA}

Infelizmente, na maioria dos casos de pedidos de aumento de licença-maternidade para a mãe cuidar do filho prematuro, não é concedido nenhum respaldo do Poder Judiciário.

Muitas mães requerem o aumento do benefício para cuidar do bebê devido a alguma complicação em sua saúde, mas mesmo assim não conseguem. ${ }^{56}$

Por outro lado, existem decisões que concedem um período de licença maior à mãe trabalhadora.

No entendimento do Tribunal de Justiça do Estado de São Paulo, a internação e as complicações decorrentes do nascimento prematuro, são justificativas plausíveis para o aumento da licença e que a legislação deve ser interpretada à luz das circunstâncias específicas do caso e sempre em ordem a dar à Lei a sua máxima eficácia, uma vez que as normas constitucionais de proteção à maternidade e à criança merecem interpretação otimizadora, que permitam a máxima efetividade, sob pena de se

\footnotetext{
${ }^{56}$ BRASIL. Tribunal de Justiça do Estado de São Paulo, 8 a Câmara de Direito Público, Agravo de Instrumento Processo $n^{\circ}$ 2013719-93.2015.8.26.0000. Agravante: Sandra Regina Souza Castilho. Agravada: Prefeitura Municipal de Itu e Instituto de previdência social dos servidores municipais de Itu - ITUPREV. Relator: Leonel Costa, data de Julgamento: 19/02/2015.
} 
estar estabelecendo restrição inaceitável ao direito constitucionalmente assegurado. $^{57}$

Em seguida, afirma ser inquestionável que licença-maternidade, antes de ser um direito da mãe, é uma garantia do filho, que poderá começar o seu desenvolvimento com a necessária atenção materna integral. Ressalta ainda que entre o suposto prejuízo econômico a ser arcado pelo INSS e os diversos valores constitucionais, como a vida, da saúde e da dignidade da pessoa humana resolve-se pela preponderância destes últimos. ${ }^{58}$

A jurisprudência não é pacífica quanto ao assunto, o que permite a interpretação de cada magistrado, situação que não pode prosseguir, tendo em vista o impacto social causado pela não concessão de um benefício especial à mãe de um prematuro.

\subsection{LEIS MUNICIPAIS SOBRE O AUMENTO DA LICENÇA PARA MÃES DE PREMATUROS}

Existem algumas leis municipais que regulam a concessão de uma licença-maternidade maior para as servidoras municipais mães de bebês pré-termo.

O período de licença é definido pelo tempo correspondente à subtração entre a $37^{\text {a }}$ semana e a idade de nascimento do bebê devidamente comprovada, somado aos 120 dias definidos na Constituição Federal.

O Presidente da Câmara Municipal do Rio de Janeiro instituiu a Lei $\mathrm{n}^{\mathrm{o}} 4.482$ de 10 de abril de 2007 que dispõe sobre a licençamaternidade especial para servidoras municipais, mães de bebês prematuros, ${ }^{59}$ e concede a licença especial da forma já explicitada.

57 BRASIL. TRF1/MG, Juizado Especial Federal 32 ${ }^{\mathrm{a}}$ Vara, Processo n ${ }^{\mathbf{o}}$ : 006294295.2013.4.01.3800 Autor(a) : Juliana Cristina Santos Ré(u) : Instituto Nacional do Seguro Social - INSS. Juiz Federal Substituto Luiz Eduardo Stancini Cardoso, Data de Julgamento: 20 de novembro de 2013.

58 Ibidem.

59 RIO DE JANEIRO. Lei $\mathbf{n}^{\mathbf{0}} \mathbf{4 . 4 8 2}$ de $\mathbf{1 0}$ de abril de 2007. Disponível em: <http://mail.camara.rj.gov.br/APL/Legislativos/contlei.nsf/e9589b9aabd9cac8032564fe00 65abb4/2cf59e6a2394e2ae032576ac007278fa?OpenDocument\&ExpandSection=-1>.

Acesso em: 02 ago. 2015. 
Contudo, foi reconhecida a inconstitucionalidade dessa lei pelo desembargador Milton Fernandes sob a justificativa que a lei afrontava o princípio da divisão de poderes. ${ }^{60}$

O mesmo ocorreu no caso da Lei Municipal de Mauá no 3.936, de 09 de março de 2006 que foi promulgada pelo Vereador Diniz Lopes dos Santos.

O Prefeito do Município de Mauá, Leonel Damo, por meio do despacho normativo 03/06, entendeu pela inconstitucionalidade da Lei em razão da violação ao princípio constitucional da separação e independência entre os poderes, remetendo-a para a Secretaria Municipal de Assuntos Jurídicos para o ajuizamento da Ação Direta de Inconstitucionalidade. ${ }^{61}$

O Município de Garuva, situado no interior do Estado de Santa Catarina concede às suas servidoras municipais o aumento da licença desde 2011, por meio da Lei Complementar $n^{\circ} 57$ de 21 de setembro de 2011.

Na exposição de motivos desta Lei, sábias palavras foram usadas como justificativa do beneficio:

A formação do vínculo entre mãe e filho não é um acontecimento imediato e as interações sucessivas na hipótese de partos antecipados são indispensáveis para a construção de um sólido vínculo materno e à prevenção de indesejáveis sequelas para mãe e filho. (...), com efeito, representa um avanço social notável e permitirá que o contato materno mais prolongado com o filho torne maiores as chances de sobrevivência desses bebês. ${ }^{62}$

${ }^{60}$ MIGALHAS. TJ/RJ declara a inconstitucionalidade de quatro leis municipais. Disponível em: <http:// www.migalhas.com.br/Quentes/17,MI69949,91041TJRJ+ declara+a+inconstitucionalidade+de+quatro+leis+municipais $>$. Acesso em: 02 ago. 2015. ${ }^{61}$ MAUÁ. Lei Municipal no 3.936, de 09 de março de 2006. Disponível em: http:// dom.maua.sp.gov.br/LegislacaoNumero .aspx?LegislaID=3936\&TipoLegislaID=0. Acesso em: 02 ago. 2015.

62 GARUVA. Lei Complementar $n^{\circ} 57$ de 21 de setembro de 2011. Disponível em: http://www.legislador.com.br/LegisladorWEB.ASP?WCI=LeiTexto\&ID=82\&inEspecieL ei=2\&nrLei=57\&aaLei=2011\&dsVerbete=prematuro. Acesso em: 02 ago. 2015. 
A cidade de São Paulo também constituiu um benefício as suas servidoras através da Lei Municipal $\mathrm{n}^{\circ} 13.379$, de 24 de junho de 2002, decretada e promulgada pela Prefeita do Município de São Paulo, Marta Suplicy, em sessão de 04 de junho de 2002. ${ }^{63}$

Em 2005, o Prefeito do Município de São Paulo, José Serra, ratificou a Lei Municipal $n^{\circ} 13.379$ de 24 de junho de 2002 regulamentando-a através do Decreto ${ }^{\circ} 46.113$, de 21 de julho de 2005.

Assim, conclui-se que embora tenha sido declarada a inconstitucionalidade das leis municipais das cidades Rio de Janeiro e Mauá, já se verifica uma preocupação por parte dos legisladores a respeito da concessão de uma licença especial às mães de prematuros.

\subsection{PROJETOS EM TRAMITAÇÃO SOBRE O AUMENTO DA DURAÇÃO DA LICENÇA MATERNIDADE}

Dentre as Propostas de Emenda à Constituição e Projetos de Lei em tramitação, sobre o tema maternidade e nascimentos prematuros destacam-se a PEC 58/11, PEC 30/07, PEC 99/15, Projetos de Lei 6388/02, 2393/03, 1164/11, 2932/08, 2220/11 e 7895/14.

A Proposta de Emenda à Constituição no 58 de 2011 foi apresentada pelo Deputado Jorge Silva e tem o objetivo de modificar o inciso XVIII do artigo $7^{\circ}$ da Constituição Federal, de modo que a licença à gestante seja estendida em casos de nascimento prematuro, somando os 120 dias mais a quantidade de dias que o recém-nascido passar internado ${ }^{64}$.

O Deputado Jorge Silva esclarece seus motivos para a proposta, tais que podem resumir o escopo do presente trabalho, deixando claramente expostas as causas tão importantes que envolvem a licençamaternidade para a mãe de uma criança prematura:

${ }^{63}$ SÃO PAULO. Lei municipal no 13.379, de 24 de junho de 2002. Disponível em: http://www.prefeitura.sp.gov.br/cidade/secretarias/upload/chamadas/113379_1314100432 .pdf. Acesso em: 02 ago. 2015

64 BRASIL. Proposta de Emenda à Constituição no 58 de 2011. Disponível em: http://www.camara.gov.br/proposicoesWeb/prop_mostrarintegra?codteor=903246\&filena $\mathrm{me}=\mathrm{PEC}+58 / 2011$. Acesso em: 02 ago. 2015. 
Imperioso se faz necessário colacionar, que a licença-maternidade contempla tanto a mãe quanto ao recém-nascido, onde ambos passam por um processo de adaptação, e no caso do nascimento prematuro sabemos que muitas vezes a criança fica internada por um longo período, contando-se neste período o prazo da indigitada licença, trazendo prejuízo e transtornos na vida da genitora e do recém-nascido.

Conforme é de conhecimento de todos, o bebê prematuro muitas vezes passa meses no hospital, e esta Emenda Constitucional busca apenas dar condições reais às mães para cuidarem de seus filhos nascidos prematuramente pelo prazo de 4 (quatro) meses contados a partir da alta hospitalar do bebê, haja vista que nos dias atuais muitas mães passam meses aguardando a indigitada alta hospitalar e quando a criança finalmente vai para casa é hora de voltar a trabalhar.

Relevante afirmar que no momento que as crianças mais precisam das mães, ou seja, quando voltam para casa após um período de luta incansável pela vida - consoante consabido, bebê prematuro costuma ser mais frágil, mais sujeito a doenças -, que necessitam ter a mãe por tempo integral, conforme demonstrado pela Sociedade Brasileira de Pediatria pelo período de 6(seis) meses, muitas vezes a licença-maternidade está quase no fim.

A louvável proposta do Deputado está aguardando a Criação de Comissão Temporária pela Mesa, e, portanto, ainda não foi aprovada.

O Projeto de Lei $n^{\circ} 6388$ de 2002 defende o aumento do período de concessão do salário e licença-maternidade à gestante em caso de parto antecipado, modificando o artigo 71 da Lei 8213 de 1991 e o $\$ 3^{\circ}$ do artigo 392 da CLT.

O objetivo da mudança é somar 120 dias de licença ao número de semanas equivalentes à diferença entre a $37^{\mathrm{a}}$ semana e a idade gestaci- 
onal que o bebê nasceu, conforme comprovação a ser realizada por médico pediatra. ${ }^{65}$

O Projeto originou-se do Projeto de Lei do Senado $n^{\circ} 190$ de 2001 de autoria do Senador Luiz Pontes e está aguardando Parecer do Relator na Comissão de Finanças e Tributação (CFT).

O Projeto de Lei n 2393 de 2003, criado pelo Deputado Bernardo Ariston, ${ }^{66}$ defendeu que o aumento da licença-maternidade deve ser feito da mesma forma que a disposta no Projeto $n^{\circ} 6388$ de 2002.

Ainda, o Projeto de Lei ${ }^{\circ} 1164$ de 2011, feito pelo Deputado Lincoln Portela, intercede pelo acréscimo do $\S 3^{\circ}$ e incisos ao Art. $1^{\circ}$ da Lei $n^{\circ} 11.770$, de 09 de setembro de $2008^{67}$, conhecida pela criação do Programa Empresa Cidadã, o dispositivo a ser adicionado reza pelo afastamento da mãe de um bebê prematuro da mesma forma defendida nos Projetos n. ${ }^{\circ}$ 6388/ 2002 e 2393/ 2003.

O Projeto de Lei $\mathrm{n}^{\circ} 2932$ de 2008 originou-se do Projeto de Lei do Senado $n^{\circ} 300$ de 2007 elaborado pelo Senador Eduardo Azeredo ${ }^{68}$.

O projeto defende a alteração do artigo 392 da CLT e do artigo 71 da Lei da Previdência Social, de forma que tanto a licençamaternidade quanto o salário-maternidade aumentem em 60 dias em casos de nascimento múltiplo, nascimento prematuro ou de criança que tenha doença ou malformação grave, que necessite de maior atenção do que um recém-nascido sem essas complicações.

Assim esclarece o Senador os argumentos do Projeto:

Tratam-se de situações nas quais a presença materna se torna ainda mais indispensável que o normal, em razão de circunstâncias específicas que cercam a

65 BRASIL. Projeto de lei $\mathbf{n}^{\mathbf{0}} \mathbf{6 3 8 8}$ de 2002. Disponível em: http://www.camara.gov.br/proposicoes Web/fichadetramitacao?idProposicao $=47173$. Acesso em: 02 ago. 2015.

${ }^{66}$ BRASIL. Projeto de lei $\mathbf{n}^{\mathbf{0}} 2393$ de 2003. Disponível em: http://www.camara.gov.br/ proposicoesWeb/fichadetramitacao?idProposicao=140072. Acesso em: 02 ago. 2015.

67 BRASIL. Projeto de lei $\mathbf{n}^{\mathbf{0}} 1164$ de 2011. Disponível em: http://www2.camara. leg.br/proposicoesWeb/fichadetramitacao?idProposicao=499594. Acesso em: 02 ago. 2015.

68 BRASIL. Projeto de lei do Senado $\mathbf{n}^{\mathbf{0}} \mathbf{3 0 0}$ de 2007. Disponível em: http://www.senado.leg.br/ atividade/materia/detalhes.asp?p_cod_mate=81332. Acesso em: 02 ago. 2015. 
gestação ou o nascimento. É o caso, por exemplo, de gestações múltiplas, de nascimento prematuro ou de crianças portadoras de enfermidades ou malformações congênitas. Em tais casos, é indiscutível que existe a necessidade de que a mãe permaneça por maior tempo junto de seu filho, quer em razão da maior quantidade de atenção a ser dispensada, quer em razão da fragilidade ainda maior dos recém-nascidos. ${ }^{69}$

Percebe-se nesse projeto a expansão da preocupação do legislador quanto aos casos em que as mães merecem uma licença especial, e que, de fato, são totalmente compreensíveis e de grande necessidade das trabalhadoras que se encaixam nas três circunstâncias expostas.

O Projeto de Lei ${ }^{\circ} 2220$ de 2011 tem origem do Projeto de Lei do Senado n 241 de 2010 de autoria da Senadora Marisa Serrano.

Consta no Projeto o acréscimo do artigo 71-B à Lei no 8.213 , de 24 de julho de 1991, para dispor sobre o salário-maternidade das seguradas mães de prematuros extremos, com a seguinte redação:

Art. 71-B. O salário-maternidade devido às seguradas, inclusive as domésticas, mães de prematuros extremos, assim definidos em regulamento, será concedido durante todo o período necessário ao acompanhamento hospitalar do recémnascido, sem prejuízo do período de licença à gestante, fixado no inciso XVIII do art. $7^{\circ}$ da Constituição Federal.

Parágrafo único. Durante o período referido no caput deste artigo que exceder o tempo de direito a afastamento fixado no inciso XVIII do art. $7^{\circ}$ da Constituição Federal, a segurada fará jus ao recebimento de benefício equivalente ao valor do

69 BRASIL. Projeto de lei do Senado $\mathbf{n}^{\mathbf{0}} \mathbf{2 9 3 2}$ de 2008. Disponível em: http://legis.senado.leg.br/mateweb/arquivos/mate-pdf/10279.pdf. Acesso em: 13. dez. 2015 
salário-de-contribuição, a ser pago na forma do regulamento ${ }^{70}$.

Nesse caso, defende-se o afastamento da mãe para cuidar de seu bebê prematuro extremo por todo o período necessário ao acompanhamento hospitalar da criança, disposição que em diversos casos é a ideal, tendo em vista os altos e baixos da vida de um bebê pré-termo e seu vagaroso desenvolvimento.

O Projeto de Lei 7895 de 2014 é de autoria da Deputada Andreia Zito e protege a ideia de que os 120 dias de licença-maternidade dispostos na CF devem ser contados a partir da alta hospitalar do recémnascido prematuro, segundo a Deputada, tal forma ajudaria a manter a isonomia entre todas as mães ${ }^{71}$.

A disposição a ser alterada é o artigo 392 da CLT, que passaria a ter um $\S 5^{\circ}$ dispondo que o início da licença contaria apenas no momento de alta do bebê prematuro.

O projeto foi apensado ao Projeto $\mathrm{n}^{\mathrm{o}} 3416$ de 2012, que por sua vez, foi apensado ao Projeto $\mathrm{n}^{\circ} 2220$ de 2011, que já foi abordado neste capítulo.

A Proposta de Emenda à Constituição n 30 de 2007 de autoria da Deputada Ângela Portela possui o objetivo de alterar o inciso XVIII do artigo $7^{\circ}$ da CF para aumentar a licença à gestante, sem prejuízo do emprego e do salário, para um período de cento e oitenta dias. ${ }^{72}$

Conforme a proposta, as principais justificativas englobam a importância do aleitamento materno nos primeiros seis meses de vida do bebê, proteger a infância, valorizar a mulher e destacar a função social do trabalho.

\footnotetext{
${ }^{70}$ BRASIL, Projeto de lei $\mathbf{n}^{\mathbf{0}} 2220$ de 2011. Disponível em: http://www.camara.gov.br/ proposicoesWeb/prop_mostrarintegra?codteor $=916808 \&$ filename $=P L+2220 / 2011$. Acesso em: 02 ago. 2015.

71 BRASIL. Projeto de lei $\mathbf{n}^{\mathbf{0}} \mathbf{7 8 9 5}$ de 2014. Disponível em: http://www.camara.gov.br/proposicoesWeb/prop_ _ mostrarintegra?codteor=1273645\&filename=PL+7895/2014. Acesso em: 02 ago. 2015.

72 BRASIL. Proposta de Emenda à Constituição $\mathbf{n}^{\mathbf{0}} 30$ de 2007. Disponível em: http://www.Camara.gov.br/proposicoesWeb/prop_mostrarintegra?codteor $=448751 \&$ filena $\mathrm{me}=\mathrm{PEC}+30 / 207$. Acesso em: 02 ago. 2015.
} 
A PEC 30 de 2007 foi apensada à PEC 515 de 2010, que possui a mesma proposta da proposta de 2007 e está pronta para pauta no Plenário.

A PEC 99/2015 do Senado, de autoria do Senador Aécio Neves, foi aprovada por unanimidade no Senado nos dois turnos e seguirá para análise da Câmara dos Deputados ${ }^{73}$. A PEC altera o inciso XVIII do art. $7^{\circ}$ da Constituição Federal, em que constará que em casos de nascimento prematuro a licença-maternidade será estendida à quantidade de dias que o recém-nascido passar internado ${ }^{74}$, ou seja, os 120 dias de licença da mãe passarão a ser contados após a saída de seu filho prematuro do hospital.

\section{CONSIDERAÇÕES FINAIS}

Percebe-se que a luta das mulheres trabalhadoras para o reconhecimento de seus direitos, necessidades e responsabilidades como mãe por parte de seus empregadores já perdura por mais de um século.

Organizações e conferências internacionais tiveram um papel de grande importância na história das conquistas femininas na esfera trabalhista, principalmente no tocante à proteção à igualdade de tratamento entre os sexos no trabalho e a proteção à maternidade.

Assim a legislação nacional foi avançando para os mesmos propósitos de igualdade e proteção até chegarem às disposições constitucionais atuais, que possuem com mais vigor a proteção à maternidade, tipificada como um direito social na Constituição vigente.

Juntamente com as normas da Constituição Federal, a Consolidação das Leis do Trabalho concede à mulher o direito a um afastamento de suas atividades antes e depois do parto no total de 120 dias para se recuperar e cuidar de seu bebê nos primeiros meses de vida.

\footnotetext{
73 JUNGMANN. Mariana. Aprovada PEC que prevê licença-maternidade para mães de bebês prematuros. Disponível em: http://agenciabrasil.ebc.com.br/politica/noticia/2015-12/aprovada-pec-que-preve-licencamaternidade-maior-para-maes-de-bebes. Acesso em 15 dez. 2015.

74 BRASIL. Proposta de Emenda Constitucional $\mathbf{n}^{\circ} 99$ de 2015. Disponível em: http://www.senado.leg.br/ atividade/rotinas/materia/getPDF.asp?t=171552\&tp=1. Acesso em: 15 dez. 2015
} 
No período de afastamento, a trabalhadora recebe o chamado salário-maternidade, que é arcado pela Previdência Social, tendo em vista que não cabe ao empregador se encarregar dos proventos de sua funcionária durante o lapso citado.

A Lei $n^{\circ} 11.770$, criada em 2011, instituiu o Programa Empresa Cidadã. O Programa concede 180 dias de licença-maternidade às empregadas da Administração Pública e empresas privadas que aderirem a ele. O período adicional é arcado pelo empregador, que recebe em troca benefícios fiscais, desde que esteja dentro das exigências legais.

Inicialmente, uma criança que nasce antes da $37^{\mathrm{a}}$ semana deve receber acompanhamento médico hospitalar até possuir as condições adequadas para ir para a casa, o que pode demorar meses dependendo da idade gestacional que o recém-nascido veio ao mundo, proporcionando em muitos casos, longas internações.

Quanto mais prematuro for o bebê, mais frágil ele é, uma vez que não possui imunidade a doenças e infecções. Além disso, como nasceu antes do tempo, ele termina seu desenvolvimento fora do útero da mãe, normalmente em uma incubadora.

Após superar todas as instabilidades, o bebê prematuro vai para casa, mas o acompanhamento continua, uma vez que muitas vezes o bebê precisa de estimulação e assistência nos primeiros anos de vida.

Frequentemente, a mãe não consegue desenvolver suas atividades no trabalho da forma esperada, uma vez que seu pensamento está em casa, ou na creche, no seu filho recém-nascido que não pode ser amparado pelos seus cuidados.

Em síntese, a prorrogação da licença-maternidade para as mães de prematuros configura um direito da criança, sendo uma questão de saúde pública que merece atenção e análise dos encarregados de melhorarem a vida do cidadão.

O apoio da mãe ao recém-nascido na primeira fase de sua vida proporcionará benefícios para toda a sociedade, tendo em vista que este será um cidadão pleno, ou seja, a mãe poderá cuidar do desenvolvimento do bebê de perto e acompanhar seu crescimento com todo o auxílio médico necessário para que o previna de eventuais doenças ou complicações, às quais o prematuro está mais exposto.

Prevenindo prejuízos no início da vida da criança, futuramente, não haverá de se falar em recuperação, que terá custos maiores do que os pagos por uma licença especial das mães que necessitarem. Ademais, os 
resultados favoráveis da presença direta da mãe na vida do prematuro são imensuráveis.

Desde 1999, alguns legisladores já tiveram a iniciativa de regularizar uma licença maior para as mães de bebês pré-termo, contudo, nenhum Projeto de Lei apresentado com esse objetivo foi aprovado até o momento. Enquanto isso, mães permanecem sem respaldo e crianças prematuras sem o apoio materno desde cedo, considerando que o período de licença é gasto em quase sua totalidade enquanto a criança ainda está hospitalizada.

Ressalta-se ainda, que a criança prematura tem direito à vida e de ter o suporte materno, sendo uma obrigação do Estado propiciar os melhores meios possíveis para isso.

Deve-se criar um benefício especial para mães necessitadas de um período maior com seu filho devido à prematuridade. Tal benefício deve ser um direito de todas as mães trabalhadoras, sem exclusões, de modo que haja uma relativização da licença especial.

Por fim, espera-se contar com a presteza de nossos legisladores para que algum benefício que trate do aumento da licença seja aprovado em breve, pois certamente trará um maior amparo para as trabalhadoras que estiverem nessa condição.

\section{REFÊRENCIAS BIBLIOGRÁFICAS}

ABC.MED. Entendendo a prematuridade e os cuidados necessários com os prematuros. Disponível em: <http://www.abc.med.br/p/s aude-da-crianca/502030entendendo-a-prematuridade-e-os-cuida dos-necessarios-com-os-prematuros.htm>. Acesso em: 31 jul. 2015.

ALEITAMENTO.COM. A Lei do Prematuro. Disponível em: http://www.aleitamento.com/campanhas/lei-prematuro.asp. Acesso em 15 nov. 2015.

ALVES, Joana. Bebê prematuro: os cuidados vão muito além da UTI neonatal. Disponível em: http://barrigudos.blogosfera.uol.com.br/2013/08/24/maes-deprematuros-precisam-de-licenca-maternidademaior/ Acesso em: 31 jul. 2015 
AVAAZ.ORG. Lei do prematuro - por que isto é importante. Disponível em: https://secure.avaaz. org/po/petition/Lei_do_ Prematuro/?pv=1. Acesso em: 01 ago. 2015.

BACHUR, Tiago Faggioni; MANSO, Tânia Faggioni Bachur da Costa. Licença-maternidade e salário-maternidade: na teoria e na prática. Franca: Lemos e Cruz, 2011.

BALOGH, Giovanna. A curta licença-maternidade das mães de prematuros. Disponível em: http://maternar.blogfolha.uol.com.br/2014/07/01/a-curta-licencamaternidade-das-maes-de-prematuros/. Acesso em: 01 ago. 2015.

BOSSA, Sônia. Direito do trabalho da mulher no contexto social brasileiro e medidas antidiscriminatórias. São Paulo: Oliveira Mendes, 1998.

BRASIL, Projeto de lei $\mathbf{n}^{\mathbf{o}} \mathbf{2 2 2 0}$ de 2011. Disponível em: http://www.camara.gov.br/ proposicoesWeb/prop_mostrarintegra?codteor $=916808 \&$ filename $=$ PL+2220/2011. Acesso em: 02 ago. 2015.

. Decreto 7.052 de 2009. Disponível em: http://www.planalto. gov.br/ccivil_03/_ato2007-2010/2009/Decreto/D7052.htm. Acesso em: 17 ago. 2015.

Decreto $\mathbf{n}^{0} 3048$ de 1999. Disponível em: http://www. planalto.gov.br/ccivil_03/decreto/d3048.htm. Acesso em: 08 out. 2015.

. Lei $\mathbf{n}^{\circ}$ 11.770, de 09 de setembro de 2008. Disponível em: http://www.planalto. gov.br/ccivil_03/_ato20072010/2008/lei/111770.htm. Acesso em: 17. ago. 2015.

Projeto de lei do Senado $\mathbf{n}^{\mathbf{3}}$ 300/2007. Disponível em: http://www.senado.leg.br/

atividade/materia/detalhes.asp?p_cod_mate $=81332$. Acesso em: 02 ago. 2015.

Projeto de lei $\mathbf{n}^{\mathbf{0}} \mathbf{1 1 6 4}$ de 2011. Disponível em: http://www.camara.gov.br/ proposicoesWeb/prop_mostrarintegra?codteor $=863118 \&$ filename $=$ PL+1164/2011. Acesso em: 02 ago. 2015.

Projeto de lei $\mathbf{n}^{\mathbf{0}} \mathbf{2 3 9 3}$ de 2003. Disponível em: http://www.camara.gov.br/

proposicoesWeb/fichadetramitacao?idProposicao=140072. Acesso em: 02 ago. 2015. 
Projeto de lei $\mathbf{n}^{\mathbf{0}} \mathbf{6 3 8 8}$ de 2002. Disponível em: http://www.camara.gov. br/proposicoes Web/fichadetramitacao?idProposicao=47173. Acesso em: 02 ago. 2015.

. Projeto de lei $\mathbf{n}^{\mathbf{0}} \mathbf{7 8 9 5}$ de 2014. Disponível em: http://www. camara.gov.br/ proposicoesWeb/prop_mostrarintegra?codteor $=1273645 \&$ filename $=$ PL+7895/2014. Acesso em: 02 ago. 2015.

. Proposta de Emenda à Constituição no 30 de 2007. Disponível em: http://www. camara.gov.br/proposicoesWeb/prop_mostrarintegra?codteor $=448$ 751\&filename=PEC+30/207. Acesso em: 02 ago. 2015.

. Proposta de Emenda à Constituição no 58 de 2011. Disponível em:

http://www.camara.gov.br/proposicoesWeb/prop_mostrarintegra?c odteor $=903246 \&$ filename $=\mathrm{PEC}+58 / 2011$. Acesso em: 02 ago. 2015.

. Proposta de Emenda Constitucional no 99 de 2015. Disponível em: http://www. senado.leg.br/atividade/rotinas/materia/getPDF.asp?t=171552\&tp= 1. Acesso em 15 dez. 2015

. Senado Federal. Projeto de lei do Senado $\mathbf{n}^{\mathbf{0}} \mathbf{2 8 1}$ de 2005. Disponível em: http://legis. senado.leg.br/mateweb/arquivos/matepdf/6716.pdf. Acesso em: 17 ago. 2015.

TJ/SP, $8^{\mathrm{a}}$ Câmara de Direito Público, Agravo de Instrumento Processo $\mathrm{n}^{\circ}$ 2013719-93.2015.8.26.0000. Agravante: Sandra Regina Souza Castilho. Agravada: Prefeitura Municipal de Itu e Instituto de previdência social dos servidores municipais de Itu - ITUPREV. Relator: Leonel Costa, data de Julgamento: 19/02/2015.

. TRF1/MG, JUIZADO ESPECIAL FEDERAL 32 ${ }^{\mathrm{a}}$ VARA, Processo $n^{\circ}$. : 0062942-95.2013.4.01.3800 Autor(a) : Juliana Cristina Santos Ré(u) : Instituto Nacional do Seguro Social - INSS. Juiz Federal Substituto Luiz Eduardo Stancini Cardoso, Data de Julgamento: 20 de novembro de 2013.

CARRION, Valentin. Comentários à CLT: legislação complementar/ jurisprudência. 39 ed. rev. e atual. por Eduardo Carrion. São Paulo: Saraiva, 2014. 
CHAVES, Adalgisa Wiedemann ...[et al]: coord: Belmiro Pedro Welter, Rolf Hanssen Madaleno. Direitos fundamentais do direito de família. Livraria do advogado. Porto Alegre, 2004.

DE MAE PARA MAE. Como cuidar de um bebê prematuro. Disponível em: http://demaeparamae.pt/ artigos/como-cuidar-bebeprematuro. Acesso em: 31 jul. 2015.

DELGADO. Maurício Godinho. Curso de direito do trabalho. 14. ed. São Paulo: LTr. 2015.

FONSECA, Luciana Mara Monti; SCOCHI, Carmen Gracinda Silvan.

Cuidados com o bebê prematuro: orientações para a família. 2 ed. Ribeirão Preto. FIERP, 2005.60 f. Cartilha Educativa (Mestrado em Enfermagem em Saúde Pública) - Escola de Enfermagem de Ribeirão Preto/USP, 2005.

FRAGA, Iara Teresinha Gama. PEDRO Eva Néri Rubim. Sentimentos das mães de recém-nascidos prematuros: implicações para a enfermagem. Revista Gaúcha Enfermagem. Porto Alegre, 2004. Disponível em: http://www.seer.ufrgs.br/RevistaGauchadeEnfermagem /article/viewFile/4497/2434. Acesso em: 31 jul. 2015.

GARUVA. Lei Complementar no 57 de 21 de setembro de 2011. Disponível em: http://www.legislador.com.br/LegisladorWEB.ASP?WCI=LeiText o\&ID=82\&inEspecieLei $=2 \&$ nrLei $=57 \&$ aaLei $=2011 \& d s$ Verbete $=p$ rematuro. Acesso em: 02 ago. 2015.

GRANADEIRO.ADV. Benefícios: quem tem direito e como requerer o salário-maternidade. Disponível em: http://www.granadeiro.adv.br/template/template_ clipping.php?Id=3005. Acesso em: 31 jul. 2015.

JORGE NETO, Francisco Ferreira; CAVALCANTE, Jouberto de Quadros Pessoa. Direito do trabalho. 7 ed. São Paulo. Atlas. 2013.

JUNGMANN. Mariana. Aprovada PEC que prevê licençamaternidade para mães de bebês prematuros. Disponível em: http://agenciabrasil.ebc.com.br/politica/noticia/2015-12/aprovadapec-que-preve-licenca-maternidade-maior-para-maes-de-bebes. Acesso em 15 dez. 2015.

MARTINS, Sergio Pinto. Direito do trabalho. 30. ed. - São Paulo: Atlas, 2014. 
MAUÁ. Lei Municipal $\mathbf{n}^{\circ} \mathbf{3 . 9 3 6}$ de 2006. Disponível em: http://dom.maua. sp.gov.br/ LegislacaoNumero .aspx? LegislaID $=3936 \&$ TipoLegislaID $=0$. Acesso em 02 ago. 2015.

MIGALHAS. TJ/RJ declara a inconstitucionalidade de quatro leis municipais Disponível em: http:// www.migalhas.com.br/Quentes/17,MI69949,91041TJRJ+declara+ a +inconstitucionalidade+de+quatro+leis+municipais. Acesso em: 02 ago. 2015

NASCIMENTO, Amauri Mascaro. Curso de direito do trabalho: história e teoria geral do direito do trabalho, relações individuais e coletivas do trabalho. 27 ed. São Paulo. Saraiva. 2012.

. Iniciação ao direito do trabalho. 37 ed. São Paulo. LTr. 2012

NASCIMENTO, Maria Beatriz R. do; ISSLER, Hugo. Aleitamento materno em prematuros: manejo clínico hospitalar. Sociedade Brasileira de Pediatria, Jornal de Pediatria, Vol. 80, N5(supl), 2004. Disponível em: http://www. scielo.br/pdf/jped/v80n5s0/v80n5s0a08.pdf. Acesso em: 31 jul. 2015.

ORGANIZAÇÃO INTERNACIONAL DO TRABALHO. Convenções ratificadas pelo Brasil. Disponível em: http://www.oitbrasil.org.br/convention. Acesso em: 16 jul. 2015.

PRONI, Thaíssa Tamarindo da Rocha Weishaupt. Proteção constitucional à maternidade no Brasil: um caso de expansão da garantia legal. São Paulo: LTr, 2013.

SILVA. Aarão Miranda da. O direito do trabalho da mulher e a maternidade. Disponível em: http://www.ambitojuridico.com.br/site/index.php?n_link= revista_artigos_leitura \&artigo_id=1751. Acesso em: 31 set. 2015.

SILVA, Homero Batista Mateus da. Curso do direito aplicado. Segurança e medicina do trabalho, trabalho da mulher e do menor. São Paulo: Campus Jurídico, 2009.

RIBEIRO, Juliana de Oliveira Xavier. Salário-maternidade à luz da proteção previdenciária. Curitiba: Juruá, 2009.

RIO DE JANEIRO. Lei $\mathbf{n}^{\mathbf{0}} \mathbf{4 . 4 8 2}$ de 10 de abril de 2007. Disponível em: http://mail.

camara.rj.gov.br/APL/Legislativos/contlei.nsf/e9589b9aabd9cac80 32564fe0065abb4/2cf59e6a2394e2ae032576ac007278fa?OpenDoc ument\&ExpandSection=-1. Acesso em: 02 ago. 2015. 
ROCHA, Sílvia Regina da. O trabalho de mulher à luz da Constituição de 1988. Rio de Janeiro: Forense, 1991.

SANTOS, Vera. Cuidados ao bebê prematuro. Disponível em: http://www.janela-aberta-familia.org/pt/content/cuidados-aobeb\%C3\%A9-prematuro. Acesso em: 25 jul. 2015.

SÃO PAULO. Lei municipal $n^{0}$ 13.379, de 24 de junho de 2002. Disponível em: http://www. prefeitura.sp.gov.br/cidade/secretarias/upload/chamadas/113379_13 14100432 .pdf. Acesso em: 02 ago. 2015

SOCIEDADE BRASILEIRA DE PEDIATRIA. Minuta do projeto para o serviço público. Disponível em: http://www.sbp.com.br/src/uploads/2014/10/minutadoprojetoparao servico publico.pdf. Acesso em: 31 jul. 2015.

TAVARES, Marcelo Leonardo. Direito previdenciário. Rio de Janeiro: Lumen Juris, 2008.

TECNOLOGIA E INFORMAÇÕES DA PREVIDÊNCIA SOCIAL DATAPREV. Requerimento de salário-maternidade informações básicas. Disponível em: http://www.dataprev.gov.br/servicos/salmat/ salmat_def.htm. Acesso em: 31. set. 2015.

UNICEF. Estudo faz alerta sobre a situação da prematuridade no Brasil.

Disponível

em: http://www.unicef.org/brazil/pt/media_25849.htm. Acesso em: 01 ago. 2015.

VEJA. Nascem 15 milhões de bebês prematuros por ano em todo o mundo.

Disponível

em: http://veja.abril.com.br/noticia/saude/nascem-15-milhoes-de-bebesprematuros-por-ano-em-todo-omundo/. Acesso em: 01 ago. 2015. 
